\title{
Warszawska Konferencja Onkologiczna
}

Warszawska Konferencja Onkologiczna odbyła się 28 listopada br. w pięknych wnętrzach Pałacu Staszica. Patronowali jej, obok dyrektora Centrum Onkologii — Instytutu im. Marii Skłodowskiej-Curie i Instytutu Hematologii iTransfuzjologii prof. Krzysztofa Warzochy, prezesi czterech wiodących onkologicznych towarzystw naukowych: Polskiego Towarzystwa Onkologicznego - prof. Jacek Fijuth, Polskiego Towarzystwa Onkologii Klinicznej — prof. Maciej Krzakowski, Polskiego Towarzystwa Chirurgii Onkologicznej — prof. Piotr Rutkowski i Polskiego Towarzystwa Radioterapii Onkologicznej - prof. Krzysztof Składowski. Zorganizowana została z pomocą grantu Fundacji im. Jakuba hr. Potockiego.

W uroczystym otwarciu Konferencji uczestniczył minister zdrowia Bartosz Arłukowicz. Korzystając z obecności prezesów Towarzystw, konsultantów krajowych, dyrektorów centrów onkologicznych i licznego grona onkologów przedstawił kierunek proponowanych zmian w związku z planami wprowadzenia pakietu onkologicznego.

Wedle słów ministra - celem i główną strategią jest założenie, by nowotwory wykrywać przy pomocy lekarzy — nie tylko onkologów, aby lekarze rodzinni (32 tys. lekarzy rodzinnych w Polsce, 6 tys. POZ) byli zmotywowani do rozpoznawania nowotworów jak najwcześniej. Planowane jest m.in. odejście od czysto kapitacyjnego systemu finansowania lekarzy POZ. Przekazane zostaną dodatkowe środki na poszerzenie możliwości wykonywania badań przez lekarzy POZ (nie zabierając ani z ambulatoryjnej opieki specjalistycznej, ani ze szpitali) w wysokości wszystkich badań wykonanych w kraju w roku 2013, niezależnie od miejsca ich wykonania. Przekazane będzie 60 proc. wszystkich wydatków ponoszonych na porady dermatologiczne i okulistyczne, na które będzie teraz obowiązywać skierowanie i pacjenci ci będą musieli trafić do POZ. Dla poprawienia

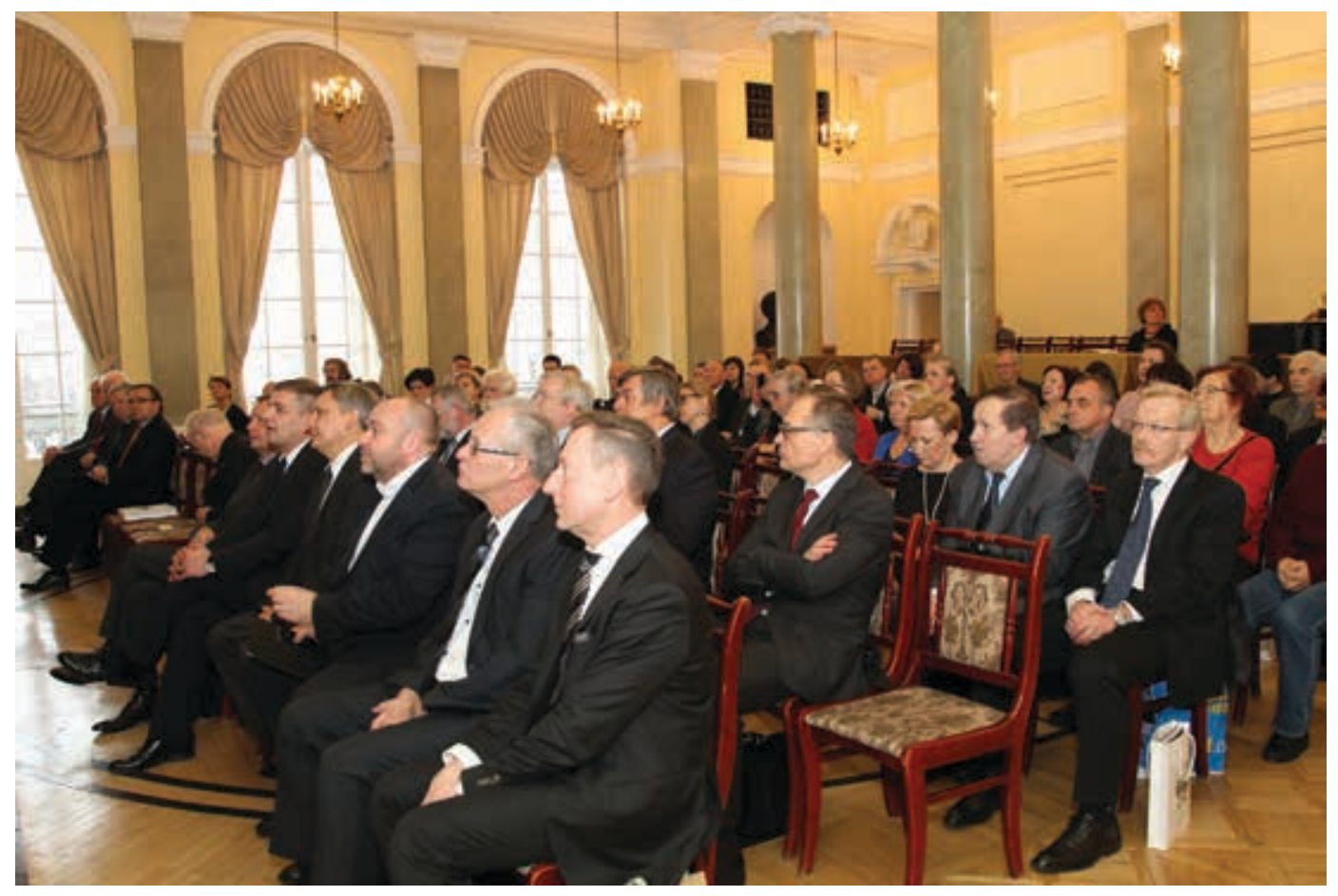

Sesja Inauguracyjna 


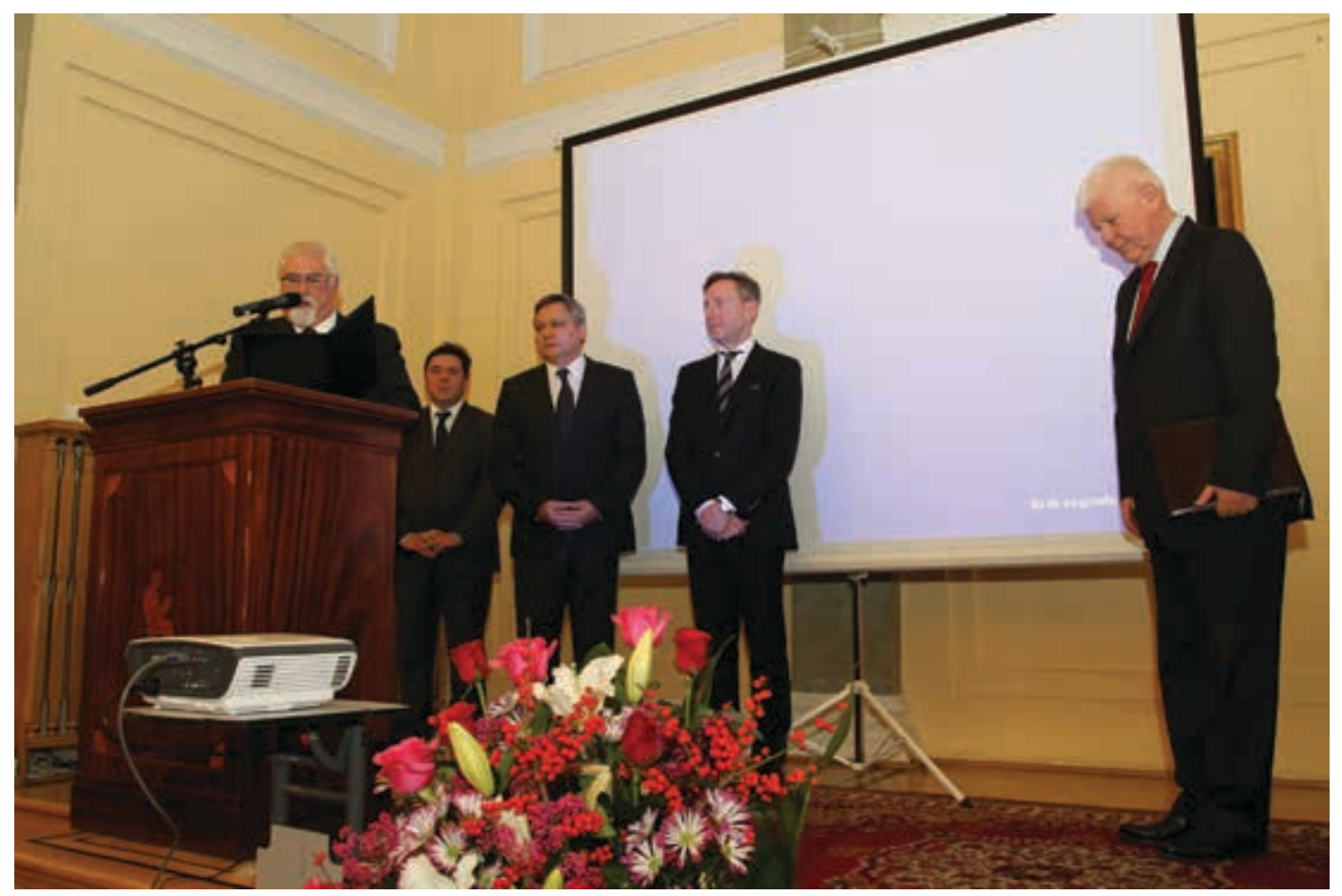

Uroczystość wręczenia prof. Marianowi Reinfussowi Dyplomów Honorowych Rady Naukowej i Dyrektora Centrum Onkologii — Instytutu im. Marii Skłodowskiej-Curie oraz Redakcji Nowotworów

sprawozdawczości lekarzy POZ zwiększone będą środki finansowe umożliwiające nabycie niezbędnego sprzętu informatycznego. Lekarz POZ uczestniczący w systemie szybkiej ścieżki onkologicznej będzie otrzymywał dodatkowe wynagrodzenie za każdego pacjenta, któremu zostanie wystawiona karta z podejrzeniem choroby nowotworowej.

Minister Arłukowicz odniósł się też do zmian wyceny świadczeń stwierdzając, że nie da się pogodzić dotychczasowych wycen ze zniesieniem limitów. Zaznaczył, że wyceny nie będzie już dokonywał płatnik - NFZ, a AOTM. Wspomniał m.in., że odsetek hospitalizacji w zakresie chemioterapii w Polsce jest jednym z najwyższych w Europie, dlatego chemioterapia, w miarę możliwości, będzie odbywała się w trybie ambulatoryjnym, jednodniowym. Zadeklarował, że zauważone błędy systemowo-organizacyjne będą korygowane w porozumieniu ze środowiskiem.

Minister wręczył odznaczenia państwowe przyznane przez Prezydenta Rzeczypospolitej Bronisława Komorowskiego: Złoty Krzyż Zasługi otrzymał prof. Zbigniew Szutkowski, a Srebrny Krzyż Zasługi — dr Jacek Gałecki.

Honorowym gościem Konferencji był prof. Marian Reinfuss. Uchwałą Rady Naukowej Centrum Onkologii — Instytutu im. Marii Skłodowskiej-Curie Pan Profesor otrzymał honorowy dyplom podkreślający jego wybitne zasługi dla onkologii polskiej, podpisany przez przewodniczącego Rady - prof. Jacka Fijutha i dyrektora Centrum — prof. Krzysztofa Warzochę. Podziękowanie za znakomitą współpracę z Redakcją Nowotworów w okresie trzech kadencji na stanowisku Przewodniczącego ZG Polskiego Towarzystwa Onkologicznego, wraz ze stosownym dyplomem, przekazał Profesorowi Reinfussowi prof. Edward Towpik.

Najwyższe wyróżnienie Oddziału Warszawskiego Polskiego Towarzystwa Onkologicznego - Członkostwo Honorowe otrzymał dr Janusz Meder; wręczył je prezes OW PTO prof. Zbigniew Nowecki.

Prof. Krzysztof Warzocha wręczył Nagrody Dyrektora dla pracowników CO-I za najlepsze publikacje zagraniczne i krajowe; nagrody za prace opublikowane w Nowotworach otrzymali: prof. Anna Gasińska, prof. Beata Sas-Korczyńska i dr Urszula Wojciechowska.

Sesję Inauguracyjną zakończył wykład prof. Edwarda Towpika nawiązujący do ważnych rocznic: 90-lecia powstania Komitetu Daru Narodowego dla Marii Skłodowskiej-Curie, 80-lecia powołania Pracowni Fizycznej w Instytucie Radowym, 40-lecia powstania pierwszej w Polsce Kliniki Chemioterapii w Instytucie Onkologii przy ul. Wawelskiej, 30-lecia Zakładu Teleradioterapii w Centrum Onkologii na Ursynowie oraz 20-lecia otwarcia pierwszej Kliniki narządowej i wykonania pierwszej operacji na Ursynowie.

W kolejnych sesjach wykłady wygłosili prezesi Towarzystw onkologicznych profesorowie: Jacek Fijuth — „Chory w podeszłym wieku jako kandydat do intensywnego leczenia onkologicznego", Maciej Krzakowski — „Leczenie systemowe — postęp i problemy", Piotr Rutkowski — „Badania kliniczne źródłem postępu w onkologii" i Krzysztof Składowski — "Predykcja efektów radioterapii - czyli poszukiwanie kamienia filozo- 


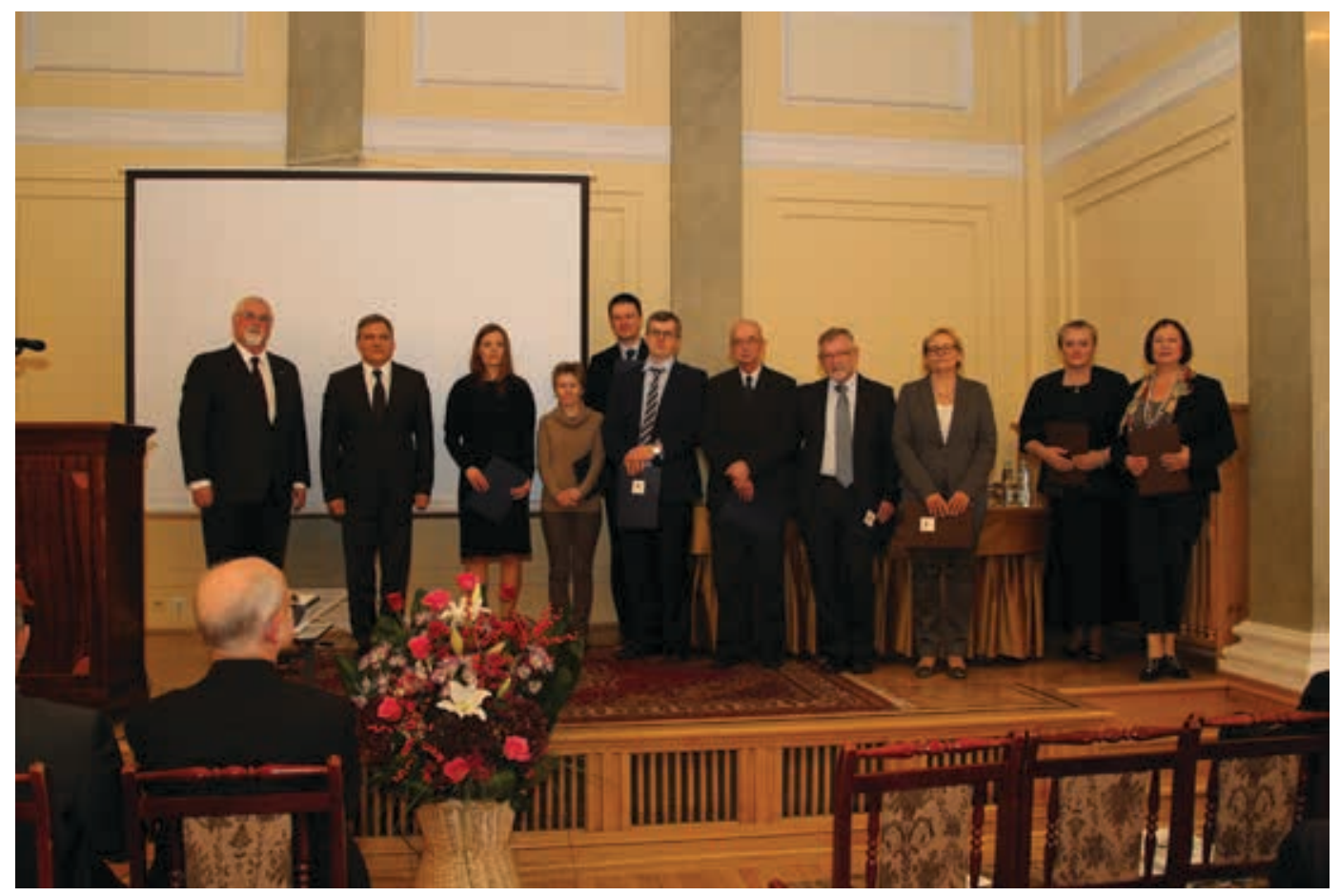

Laureaci Nagród Dyrektora CO-I za najlepsze publikacje

Fotografie: dr Sławomir Mazur

ficznego" oraz profesorowie: Krzysztof Herman — „Przyszłość chirurgii onkologicznej", Radzisław Kordek — „Progesteron — nowe szlaki w raku piersi", Bogusław Maciejewski — „Mówić czy nie mówić prawdę chorym na nowotwory?", Jan Walewski — "Serendipity w drodze do skutecznego leczenia: początki i perspektywy immunochemioterapii, czyli od nitrogranulogenu do receptorów chimerowych", Jerzy Windyga — „Powikłania zakrzepowo-zatorowe w chorobie nowotworowej: zasady postępowania” i Witold Zatoński — „Czy przegrywamy walkę z rakiem? Epidemiologia nowotworów złośliwych w Polsce". Wykładowcy tej rangi zapewnili Konferencji bardzo wysoki poziom merytoryczny, sala wypełniona była do zakończenia obrad. Należy oczekiwać, że w przyszłym roku zorganizowana będzie II Warszawska Konferencja Onkologiczna.

\section{Dr n. med. Sławomir Mazur}

Klinika Nowotworów Piersi i Chirurgii Rekonstrukcyjnej Centrum Onkologii — Instytut im. Marii Skłodowskiej-Curie w Warszawie 